\title{
PENALARAN ATAS PERSAMAAN AKUNTANSI vs PERSAMAAN MATEMATIKA
}

\author{
Sri Suryaningsum ${ }^{1}$ \\ Universitas Pembanagunan Nasional "Veteran" Yogyakarta \\ Email: suryaningsumsri@yahoo.com
}

\begin{abstract}
This article is a critical review of the authors expressed of mathematical equations by Warsono et al (2009a, 2009b, 2009c) in Accounting Introduction to learning. This critical review discusses in detail that the accounting equation is not a mathematical equation, the accounting equation with the concept of unity of effort, GAAP (accounting principles generally acceptable), and articulation antarlaporan in accounting information.

Learning objectives Introduction to Accounting course is not just skill alone. Introduction to Accounting course is designed with the goal of fully accounting memahamkan/mengenalkan not to menerampilkan learners to simply analyze the transaction and journaling. Accounting implications in the learning process will be described in detail the cause (why) reasoning errors accounting equation and how its impact on the process of creating the phenomenon of insight and attitudes towards accounting.
\end{abstract}

Keywords: Accounting Equation, Mathematical Equations, The Concept Of Unity Of Effort, GAAP, Accounting Learning

\section{LATAR BELAKANG}

Artikel ini mengkaji secara kritis berkaitan persamaan akuntansi yang dibuat menjadi persamaan matematika oleh Warsono dkk (2009a, 2009b, 2009c). Persamaan akuntansi adalah bagian dari pemahaman proses transaksi akuntansi selama perioda tertentu dengan mendasarkan pada konsep kesatuan usaha. Hal ini merupakan suatu hal yang lazim dalam membahas proses pembelajaran akuntansi pengantar. Seharusnya persamaan matematika sudah tidak relevan lagi jika dikaitkan dengan kemajuan penelitian dalam bidang akuntansi, namun demikian persamaan matematika menjadi bahasan yang cukup luas di antara dosen pengampu mata kuliah Akuntansi Pengantar dan kalangan dunia pendidikan akuntansi, khususnya di perguruan tinggi yang menyelenggarakan Jurusan Akuntansi di wilayah DIY sejak tahun 2009 sampai dengan artikel ini ditulis. Artikel ini merupakan argumen ilmiah

\footnotetext{
${ }^{1}$ Dr. Sri Suryaningsum, S.E., Ak., C.A., M.Si. adalah dosen FE Universitas Pembangunan Nasional "Veteran" Yogyakarta.

Penulis menghaturkan terima kasih atas masukan dan diskusi dengan Junaidi, M.Si. (Dr. Cand.), Yossi, M.Si. (Dr. Cand.), Prof. Suwardjono, Ph.D. dan teman-teman kolega yang pernah berdiskusi mengenai topik ini. Artikel ini merupakan penyempurnaan dan lanjutan dari artikel Mengapa Mengajar Akuntansi dengan Pilar Matematika dalam Prosiding Semnas UPNVY 2010.
} 
yang berisi ketidaksetujuan atas persamaan akuntansi yang dibuat menjadi persamaan matematika oleh Warsono dkk (2009a, 2009b, 2009c). Artikel ini penting, karena persamaan matematika akan mempengaruhi penalaran yang tidak tepat dalam memahami akuntansi pengantar. Kalau dipandang dari kemajuan penelitian akuntansi, memang memprihatinkan karena sepertinya harus berhenti sejenak dengan isu normatif yang seharusnya tidak perlu diperdebatkan lagi, karena perkembangan penelitian akuntansi normatif maupun positif sudah sangat maju. Hal ini sesuai dengan yang dikemukakan oleh Baridwan (2000) bahwa perkembangan teori akuntansi berkembang mencakup berbagai bidang antara lain dalam bidang pasar modal, keperilakuan, keagenan, dan konsekuensi ekonomi. Hal serupa juga dinyatakan oleh Nahartyo (2011) dan Supriyadi (2011).

Persamaan matematika yang diuraikan dalam artikel dan buku Warsono dkk (2009a, 2009b, 2009c) sangat menarik dan mengusik. Hal ini biasanya terjadi pada saat seseorang pertama kali mengenal akuntansi, apalagi jika orang tersebut semasa sekolah menengah atas berasal dari jurusan IPA maka akan berpikir membuat persamaan matematika, yaitu menempatkan unsur-unsur dengan tanda-tanda yang sama (positif atau negatif) pada sisi yang sama.

Warsono dkk (2009a, 2009b, 2009c) beralasan bahwa perlu menempatkan unsurunsur dengan tanda-tanda yang sama (positif atau negatif) pada sisi yang sama dalam membuat persamaan matematika dengan memindahkan Elemen Biaya ke sisi kiri bersanding dengan elemen Aset yang merupakan fungsi penjumlahan Kewajiban, Ekuitas, dan Pendapatan. Untuk itu dibuat definisi sumber penggunaan dana dan sumber pemerolehan dana. Lebih lanjut Warsono dkk (2009a, 2009b, 2009c) menyatakan bahwa sangat sulit menemukan buku literatur Akuntansi Pengantar yang menggunakan persamaan matematika dan sangat membutuhkan tanggapan atas persamaan matematika yang telah dikemukakan tersebut.

Penulis mencoba menelaah secara kritis apa yang telah dikemukakan oleh Warsono dkk (2009a, 2009b, 2009c). Ketidaksetujuan penulis tentang persamaan matematika tersebut dilandasi dengan argumen ilmiah mengenai definisi sumber penggunaan dana dan sumber pemerolehan dana yang dibuat Warsono dkk (2009a, 2009b, 2009c), penalaran konsep kesatuan usaha, PABU (prinsip akuntansi berterima umum), dan implikasinya dalam dunia pendidikan.

Penulis akan menguraikan secara rinci bahwa persamaan akuntansi bukanlah persamaan matematika. Hal ini pula yang menyebabkan bahwa semua penulis buku akuntansi pengantar selalu menekankan persamaan akuntansi dengan konsep kesatuan usaha dan menggambarkan hubungan antarlaporan keuangan (interrelationship menurut Reeve, dkk 2010, Weigant dkk 2011), artikulasi laporan keuangan (Suwardjono, 2010, 1999a, 1999b), Sugiri dan Riyono (2008).

Persamaan akuntansi merupakan bagian penting dalam proses pembelajaran akuntansi. Uraian secara rinci mengenai implikasi proses pembelajaran Akuntansi Pengantar dalam memahami persamaan akuntansi merupakan hal yang penting, karena boleh jadi jika terjadi kesalahan dalam strategi pembelajaran maka akan berpikir bahwa persamaan akuntansi dianggap bisa dibuat menjadi persamaan matematika dengan menempatkan unsurunsur dengan tanda-tanda yang sama (positif atau negatif) pada sisi yang sama.

Penciptaan fenomena memahamkan persamaan akuntansi sebagai simbol fungsional konsep kesatuan usaha secara benar dapat dilakukan setelah mahasiswa memahami seluk beluk proses perekayasaan laporan keuangan dan dunia akuntansi dalam dinamika ekonomika 
busines $^{2}$. Dalam ranah ilmu sosial, proses menciptakan fenomena adalah hal yang nyata bisa terjadi. Hal Fenomena dapat diciptakan adalah sesuai dengan Supriyadi (2011) dan Nahartyo (2011). Nahartyo (2011) menyatakan bahwa peran teori di dalam khasanah ilmu sosial bukan terbatas hanya pada penjelasan dan prediksi fenomena, namun juga penciptaan fenomena.

Penciptaan fenomena memahami bidang ilmu akuntansi adalah luas, tidak sekadar debit dan kredit dalam dunia pendidikan akuntansi diawali dengan proses pembelajaran pada awal kuliah di bidang ilmu ekonomika dan busines. Dalam hal ini, adalah proses pembelajaran mata kuliah Akuntansi Pengantar menjadi sangat penting. Yusuf (1998) menyatakan bahwa bangunan pengetahuan akuntansi yang dimiliki mahasiswa kelak, akan banyak dipengaruhi oleh keberhasilan pengajaran mata kuliah ini sebagai fundamennya. Suwardjono (1992, 1999a, 1999b) menekankan bahwa strategi pembelajaran yang tepat dalam proses pembelajaran Akuntansi Pengantar akan sangat menentukan perilaku dan wawasan berpikir terhadap akuntansi.

Hal-hal yang diuraikan di atas merupakan perbedaan pandangan penulis atas persamaan matematika yang dibuat oleh Warsono dkk (2009a, 2009b, 2009c). Dalam kajian kritis ini berisi argumen ilmiah atas ketidaksetujuan penulis mengenai persamaan matematika yang ada dalam artikel dan buku Warsono dkk (2009a, 2009b, 2009c). Landasan dalam mengkaji persamaan matematika yang dinyatakan oleh Warsono dkk (2009a, 2009b, 2009c) ini, dimotivasi oleh pertanyaan-pertanyaan penulis berikut ini:

1. Mengapa harus membuat persamaan matematika untuk persamaan akuntansi? Apakah benar alasan membuat persamaan matematika ini? Apa bedanya persamaan akuntansi (Aset $=$ Kewajiban + Ekuitas + Pendapatan - Biaya $)$ yang menurut Warsono dkk (2009a, 2009b, 2009c) merupakan persamaan konvensional dengan persamaan matematika (Aset + Biaya $=$ Kewajiban + Ekuitas + Pendapatan $)$ yang dikemukakan oleh Warsoono dkk? Apakah hanya sekadar memindah Biaya dari sisi kiri (-) ke sisi kanan (+).

2. Konsep kesatuan usaha merupakan konsep dasar dalam persamaan akuntansi, namun demikian apakah benar penerapan konsep kesatuan usaha dalam persamaan matematika yang digugungkan oleh Warsono dkk (2009a, 2009b, 2009c) tersebut?

3. PABU sebagai pilar dalam persamaan akuntansi adalah suatu keharusan, namun demikian bagaimana penerapan PABU dalam persamaan matematika digugungkan oleh Warsono dkk (2009a, 2009b, 2009c) tersebut?

4. Bagaimana implikasi persamaan matematika terhadap informasi akuntansi dan artikulasi keuangan? Untuk informasi apa biaya tersebut? Apakah sekadar hanya merefleksikan besarnya biaya? Apakah makna biaya?

5. Apakah implikasinya bagi dunia pendidikan akuntansi?

\section{PEMBAHASAN}

\section{A. Persamaan Konvensional vs Persamaan Matematika}

Penulis sangat tertarik dan terusik dengan persamaan akuntansi yang kemudian dipilah oleh Warsono dkk (2009a, 2009b, 2009c) dengan istilah persamaan konvensional dan persamaan matematika. Persamaan akuntansi dipilah oleh Warsono dkk (2009a, 2009b, 2009c) menjadi persamaan konvensional dan persamaan matematika. Persamaan

\footnotetext{
${ }^{2}$ Istilah busines adalah penyerapan yang tepat sesuai dengan kaidah-kaidah dalam Pedoman Umum Pembentukan Istilah.
} 
konvensional adalah definisi yang dikemukakan oleh Warsono dkk (2009a, 2009b, 2009c). Persamaan konvensional ini merupakan persamaan akuntansi yaitu aset sama dengan penjumlahan kewajiban, ekuitas, pendapatan yang dikurangi biaya. Persamaan akuntansi konvensional adalah Aset $=$ Kewajiban + Ekuitas + Pendapatan - Biaya .

Persamaan matematika merupakan istilah yang dikemukakan oleh Warsono dkk (2009a, 2009b, 2009c). Menurut Warsono dkk (2009a, 2009b, 2009c) persamaan matematika adalah asset plus biaya sama dengan penjumlahan kewajiban, ekuitas, dan pendapatan.

Persamaan matematika menurut Warsono dkk (2009a, 2009b, 2009c) adalah Aset + Biaya = Kewajiban + Ekuitas + Pendapatan.

Warsono dkk (2009a, 2009b, 2009c) mengemukakan bahwa persamaan matematika lebih tepat dibandingkan dengan persamaan akuntansi konvensional. Warsono dkk (2009b) menyatakan bahwa akuntansi matematika membutuhkan tanggapan. Kajian ini akan menelaah secara kritis atas definisi persamaan akuntansi, pilar matematika, penggunaan debit kredit, yang dinyatakan dalam Warsono dkk (2009a, 2009b, 2009c).

Penetapan dan pendefinisian ini penting karena untuk menghindari kemungkinan terjadinya penggunaan konsep-konsep menurut "selera" sendiri tanpa pegangan yang jelas. Hal ini sesuai yang diungkapkan oleh Kirk dalam Suwardjono (1992). Berkaitan dengan hal ini, penulis merasa khawatir bahwa hal ini terjadi juga pada konsep persamaan matematika yang dikemukakan oleh Warsono dkk (2009a, 2009b, 2009c). Persamaan matematika dimunculkan lebih dahulu dalam Warsono dkk (2009c yang berkoda ssrn 1439057) baru kemudian dibuat definisi akibat persamaan matematika tersebut dengan menyebutnya mendefinisi ulang elemen-elemen laporan keuangan dalam Warsono, dkk (2009b yang berkoda ssrn 1439084). Definisi yang dikemukakan akibat persamaan matematika ini adalah sumber penggunaan dana $(A+B)$ dan sumber pemerolehan dana $(K+E+P)$. Pertanyaan yang muncul adalah apakah hal ini dibenarkan? Jika hal ini dibenarkan, maka akibatnya kepada standar adalah standar akuntansi tidak akan pernah konsisten karena mengikuti "selera". Selera disini adalah selera akibat menciptakan persamaan matematika dari persamaan akuntansi. Persamaan matematika diciptakan dengan alasan bahwa notasi tanda positif harus sama antara sisi kanan dan kiri. Secara matematis adalah memungkinkan untuk dipindah berdasarkan hukum-hukum matematika, namun demikian muncul pertanyaan apakah tidak mempengaruhi makna dari persamaan akuntansi? Tentu saja mempengaruhi makna dari persamaan akuntansi. Karena tidak ada maknanya antara Aset+Biaya maka Warsono dkk (2009a, 2009b) menciptakan Aset+Biaya adalah sumber penggunaan dana. Untuk Kewajiban+Ekuitas+Pendapatan didefinisi dengan sumber pemerolehan dana. Uraian di bawah ini akan menunjukkan rancunya definisi sumber penggunaan dana dan sumber pemerolehan dana.

Persamaan matematika yang digugungkan oleh Warsono dkk (2009a, 2009b, 2009c) adalah dengan memindah akun Biaya ke sisi kanan sehingga sekelompok dengan akun Aset, sehingga menjadi persamaan Aset + Biaya $=$ Kewajiban + Ekuitas + Pendapatan. Berikut ini adalah kutipan dari Warsono dkk (2009a, 2009b, 2009c) dalam menurunkan persamaan matematika:

Menggunakan pendekatan matematika, elemen Biaya dan elemen Pengembalian ekuitas merupakan jenis penggunaan dana sebagaimana elemen Aset, sedangkan elemen Pendapatan merupakan sumber pemerolehan dana sebagaimana elemen Utang dan Ekuitas. Dengan demikian PEA (Persamaan Ekstensi Akuntansi) Matematika dapat dituliskan berikut ini: 
Aset+Biaya+Pengembalian Ekuitas $=$ Kewajiban + Ekuitas + Pendapatan

\{Jenis-jenis penggunaan dana $\}$
\{Sumber-sumber pemerolehan dana\}

Dapat disimpulkan bahwa Warsono dkk (2009a, 2009b, 2009c) mengunggungkan persamaan akuntansi dengan pendekatan matematika berdasarkan pada penggunaan dan pemerolehan dana. Apakah valid aset dikelompokkan dalam jenis penggunaan dana? Apakah sebenarnya aset? Aset memang diperoleh dengan menggunakan dana, namun demikian aset akan memiliki manfaat ekonomi masa depan yang terwujud dalam aset dapat mengalir dalam perusahaan dengan beberapa cara, yaitu memproduksi barang dan jasa yang dijual oleh perusahaan, dipertukarkan dengan aset lain, digunakan untuk menyelesaikan kewajiban, dan dibagikan kepada para pemilik perusahaan (Kerangka Dasar Penyusunan Penyajian laporan Keuangan), (IASC, Framework for The Preparation and Presentation of Financial Statements).

Menurut penulis, Warsono dkk (2009a, 2009b, 2009c) terlalu menyederhanakan jika elemen Aset dikelompokkan sebagai penggunaan dana. Aset sendiri terdiri dari aset lancar, investasi jangka panjang, tanah, bangunan, perlengkapan, aset tak berwujud, dan aset lainlain. Contoh sederhana adalah akun Piutang. Akun Piutang ini termasuk dalam Aset Lancar. Jika Aset dikelompokkan sebagai pengguna dana, lalu bagaimana dengan akun Piutang yang notabene merupakan bagian dari elemen Aset? Apakah Piutang menggunakan dana? dalam PSAK No. 9 dinyatakan bahwa piutang merupakan salah satu dari jenis aktiva lancar, yaitu aktiva yang diharapkan dapat direalisasikan dalam waktu satu tahun atau dalam siklus operasi normal perusahaan, mana yang lebih lama. Piutang adalah klaim untuk menerima kas akibat penyerahan barang atau jasa perusahaan (Weigant dkk, 2011: 348), Suwardjono (2010: 75).

IAI membuat Kerangka Dasar Penyusunan Penyajian Laporan Keuangan, yang menyatakan bahwa manfaat ekonomi masa depan yang terwujud dalam aset adalah potensi dari aset tersebut untuk memberikan sumbangan, baik langsung maupun tidak langsung, arus kas dan setara kas kepada perusahaan. Potensi tersebut dapat berbentuk sesuatu yang produktif dan merupakan bagian dari aktivitas operasional perusahaan. Berdasarkan definisi Aset dari sumber yang memiliki autoritas dalam akuntansi (PSAK oleh IAI) elemen Aset bukanlah merupakan kelompok penggunaan dana. Pertanyaan yang muncul dari pembuatan definisi Aset sebagai kelompok penggunaan dana oleh Warsono dkk (2009a, 2009b, 2009c) adalah apakah ketika membuat pernyataan bahwa Elemen Aset adalah kelompok pengguna dana oleh Warsono dkk (2009a, 2009b, 2009c) tidak mempertimbangkan definisi dari pihak autoritas akuntansi?

Reeve dkk (2009) mendefinisikan aset sebagai sumber daya perusahaan. Weigant dkk (2011) menyatakan bahwa asset adalah sumberdaya yang dimiliki perusahaan yang memiliki kapasitas untuk menyediakan jasa atau keuntungn masa mendatang. Suwardjono (2010) menyatakan bahwa aset adalah manfaat ekonomik masa datang yang cukup pasti yang diperoleh atau dikuasai oleh suatu entitas sebagai hasil transaksi atau kejadian masa lalu. Suwardjono (2010) menyatakan bahwa untuk dapat disebut sebagai objek atau pos harus mempunyai karakteristik sebagaiberikut: mempunyai manfaat ekonomik yang cukup pasti di masa datang, dikuasai oleh perusahaan, dan timbul karena transaksi masa lalu.

Jika pengelompokan aset adalah jenis penggunaan dana maka hal ini berkonotasi mengurangi kekayaan perusahaan. Konotasi ini justru bertentangan dengan paragraph 90 (IAI, Kerangka Dasar Penyusunan Penyajian Laporan Keuangan) yang menyatakan bahwa aset tidak diakui dalam neraca kalau pengeluaran telah terjadi dan manfaat ekonominya dipandang tidak mungkin mengalir ke dalam perusahaan setelah perioda akuntansi berjalan. 
Sebagai alternatif transaksi semacam itu menimbulkan pengakuan biaya dalam laporan laba rugi.

Pertanyaannya adalah apakah persamaan matematika yang dikemukakan oleh Warsono dkk (2009a, 2009b, 2009c) tepat atas aset (sumberdaya perusahaan) ditambah dengan biaya $=$ utang + ekuitas +pendapatan? Definisi biaya menurut FASB dalam Suwardjono (2010: 185) adalah aliran keluar aset atau penyerapan aset lainnya pada suatu entitas atau penimbulan kewajiban entitas tersebut (atau kombinasi keduanya) dari penyerahan atau produksi barang, pemberian/penyerahan jasa, atau kegiatan lain yang membentuk operasi sentral atau utama dan belanjut dari entitas tersebut. Definisi biaya menurut Weygant dkk (2011), biaya adalah kos atas aset yang telah dikonsumsi atau jasa yang digunakan dalam proses menghasilkan pendapatan. Jika Warsono dkk (2009a, 2009b, 2009c) melakukan pengelompokan Aset + biaya, apakah hal ini tidak berpotensi menimbulkan kerancuan, karena Biaya merupakan konsumsi kos atas asset dalam proses menghasilkan pendapatan. Dari definisi-definisi ini secara sederhana dapat dinyatakan bahwa secara tidak langsung besar kecilnya Aset dipengaruhi oleh Biaya, bukan Aset + Biaya.

\section{B. Konsep Kesatuan Usaha dan Artikulasi Antarlaporan Keuangan dalam Persamaan Akuntansi}

Berikut ini adalah kutipan langsung mengenai implikasi persamaan matematika dari Warsono dkk (2009c: 51):

...Anggaplah, Aset=10, Biaya $=5$, Pengembalian Ekuitas=3, Utang=2, Ekuitas=7, dan Pendapatan $=9$. Persamaan akuntansi matematikanya adalah $10+5+3=2+7+9$. Mendasarkan diri pada the ordered pairs of the group of differences contruction maka asset yang bernilai 10 dapat dituliskan salah satu berikut ini, yaitu alternative (a) 14 di sisi debet dan 4 di sisi kredit, atau alternative (b) 4 di sisi debet dan 14 di sisi kredit. Secara matematika, alternative (a) yang harus digunakan karena asset bernilai positif dan berada di sisi kiri persamaan akuntansi. Dan seterusnya... ${ }^{3}$

Pertanyaan yang muncul atas kutipan halaman 51 Warsono dkk (2009a) adalah:

1. Apakah nilai ini $(10+5+3)$ tepat untuk nilai sumber pemerolehan dana?

2. Bagaimanakah menjelaskan hasil persamaan matematika yang dibuat dalam Warsono dkk (2009c:51) tersebut?

Penulis mencoba mengkaji berdasarkan uraian tentangan dua pengelompokkan untuk menjelaskan persamaan matematika yang dikemukakan oleh Warsono dkk (2009a, 2009b, 2009c) yaitu kelompok penggunaan dana dan kelompok pemerolehan dana. Dengan alasan bahwa persamaan matematis (Warsono, 2009c) menjadi lebih tepat karena menempatkan unsur-unsur dengan tanda-tanda yang sama (positif atau negatif) pada sisi yang sama, maka Warsono (2009a, 2009b, 2009c) membuat persamaan matematika untuk persamaan akuntansi, Persamaan matematika tersebut adalah Aset ditambah Biaya sama dengan penjumlahan Kewajiban, Ekuitas, dan Pendapatan. Persamaan akuntansi adalah Aset merupakan fungsi penjumlahan Keewajiban dengan Ekuitas, selama satu perioda kondisi Ekuitas bisa berubah akibat transaksi usaha dari Pendapatan yang dikurangi dengan Biaya. Ekuitas harus dihitung lebih dahulu dengan Pendapatan yang dikurangi dengan Biaya. Jika

\footnotetext{
${ }^{3}$ Ini adalah kutipan atas paragraf pertama halaman 51, Warsono dkk (2009a). Penulis merasa perlu mencetak tebal setelah angka-angka dalam persamaan akuntansi matematika, karena berasumsi uraian yang dicetak tebal ini adalah stratagem belaka, akibat persamaan akuntansi matematika tersebut tidak mampu menjelaskan konsep kesatuan usaha.
} 
demikian simulasi angka yang diberikan akan menghasilkan nilai yang berbeda untuk persamaan matematika (Warsono, 2009a, 2009b, 2009c) dan persamaan akuntansi konvensional. Warsono (2009a; 51) memberikan ilustrasi jika Aset=10, Biaya=5, Pengembalian Ekuitas $=3$, Utang $=2$, Ekuitas $=7$, dan Pendapatan=9. Persamaan akuntansi matematikanya adalah $10+5+3=2+7+9$, memang benar angka yang diperoleh di sisi kanan sama dengan angka yang diperoleh di sisi kiri, yaitu sebesar $13=13$. Pertanyaannya adalah apakah arti angka tersebut? Jika pembuatan persamaan akuntansi matematika yang dikemukakan oleh Warsono dkk (2009a, 2009b, 2009c) adalah berdasarkan penggunaan dan pemerolehan dana, maka artinya adalah Penggunaan dana dan pemerolehan dana adalah sebesar 13. Apakah benar demikian? Tentu tidak benar, karena tidak mampu menjelaskan konsep kesatuan usaha. Padahal dengan jelas Warsono dkk (2009a) mengutip konsep kesatuan usaha dalam menjelaskan ekuitas dan bahkan subbab tertulis PABU namun isinya adalah kesatuan usaha saja. Karena persamaan matematika yang dikemukakan oleh Warsono dkk (2009a, 2009b, 2009c) tidak dapat digunakan untuk menjelaskan konsep kesatuan usaha, maka boleh jadi terjadilah stratagem seperti yang diuraikan dalam halaman 51 (Warsono dkk, 2009a).

Dalam kutipan Warsono dkk (2009c:51) tersebut, setelah memunculkan persamaan matematika beserta angkanya tersebut, selanjutnya tidak ada keterangan apapun atau argumen apapun yang menjelaskan implikasi persamaan akuntansi matematika tersebut. Keterangan yang diberikan dibawah implikasi persamaan matematika dalam halaman 51 dan selanjutnya adalah contoh stratagem, argumen yang tidak jelas dan tidak ada kaitannya dengan persamaan matematika yang diuraikan pada awal paragraf. Hal ini menunjukkan bahwa persamaan akuntansi bukan persamaan matematika. Hal ini sesuai dengan yang dinyatakan oleh Suwardjono (1999a, 1999b, 2010,a, 2010b), yang secara tegas menyatakan bahwa persamaan akuntansi bukanlah persamaan aljabar, sehingga suku di ruas kanan tidak dapat dipindah ke ruas kiri (atau sebaliknya) dengan sembarangan semata-mata untuk menghindari tanda negatif. Kalau suku persamaan di ruas kanan dipindah ke ruas kiri, konsep dasar kesatuan usaha tidak berlaku lagi dan persamaan akuntansi menjadi hilang maknanya. Hal serupa juga dinyatakan oleh Revee dkk (2010), yang menjelaskan persamaan akuntansi dengan penjelasan interrelationship.

Jika angka-angka yang dikemukakan oleh Warsono dkk (2009a), penulis operasionalkan dengan menggunakan persamaan akuntansi maka akan diperoleh Aset = Kewajiban + Ekuitas + (pendapatan-Biaya-Pengembakian Ekuitas) $\} .10=2+\{7+(9-5-3\}$. $10=2+\{7+(1)\} .10=2+8$. Arti dari persamaan akuntansi ini adalah Aset menjadi 10 karena nilai kewajiban 2 dan ekuitas menjadi 8 akibat perubahan ekuitas selama satu perioda adalah 1.

Persamaan akuntansi mampu menjelaskan artikulasi laporan keuangan, sedangkan persamaan akuntansi matematika yang dikemukakan oleh Warsono dkk (2009a, 2009b, 2009c) tidak mampu menjelaskan artikulasi laporan keuangan. Perubahan selama satu perioda akan mempengaruhi terjadinya perubahan Aset, Kewajiban, Ekuitas akibat Pendapatan dan Biaya, sesuai dengan yang dikemukakan oleh Suwardjono (1999a, 1999b, 2010, 2011); Sugiri dan Riyono (2008), Reeve dkk (2010), Weigant dkk (2011).

Pertanyaan selanjutnya untuk persamaan matematika yang dikembangkan oleh Warsono (2009a, 2009b, 2009c) adalah bagaimana dengan informasi akuntansi dan artikulasi laporan keuangannya? Tidak ada informasi akuntansi dan artikulasi laporan keuangan yang bisa dijelaskan selain arti penggunaan dana dan pemerolehan dana, padahal tujuan akuntansi adalah memberikan informasi akuntansi dari artikulasi laporan keuangan. Reeve, dkk; Weygant menyebutnya dengan interrelationship, sedangkan Suwardjono (1999a, 199b, 2010, 2010) menyebutnya dengan artikulasi antarlaporan. Weygant dkk (2011) memberikan 
ilustrasi terjadinya perubahan modal sebagai akibat dari persamaan akuntansi sebagaimana berikut ini:

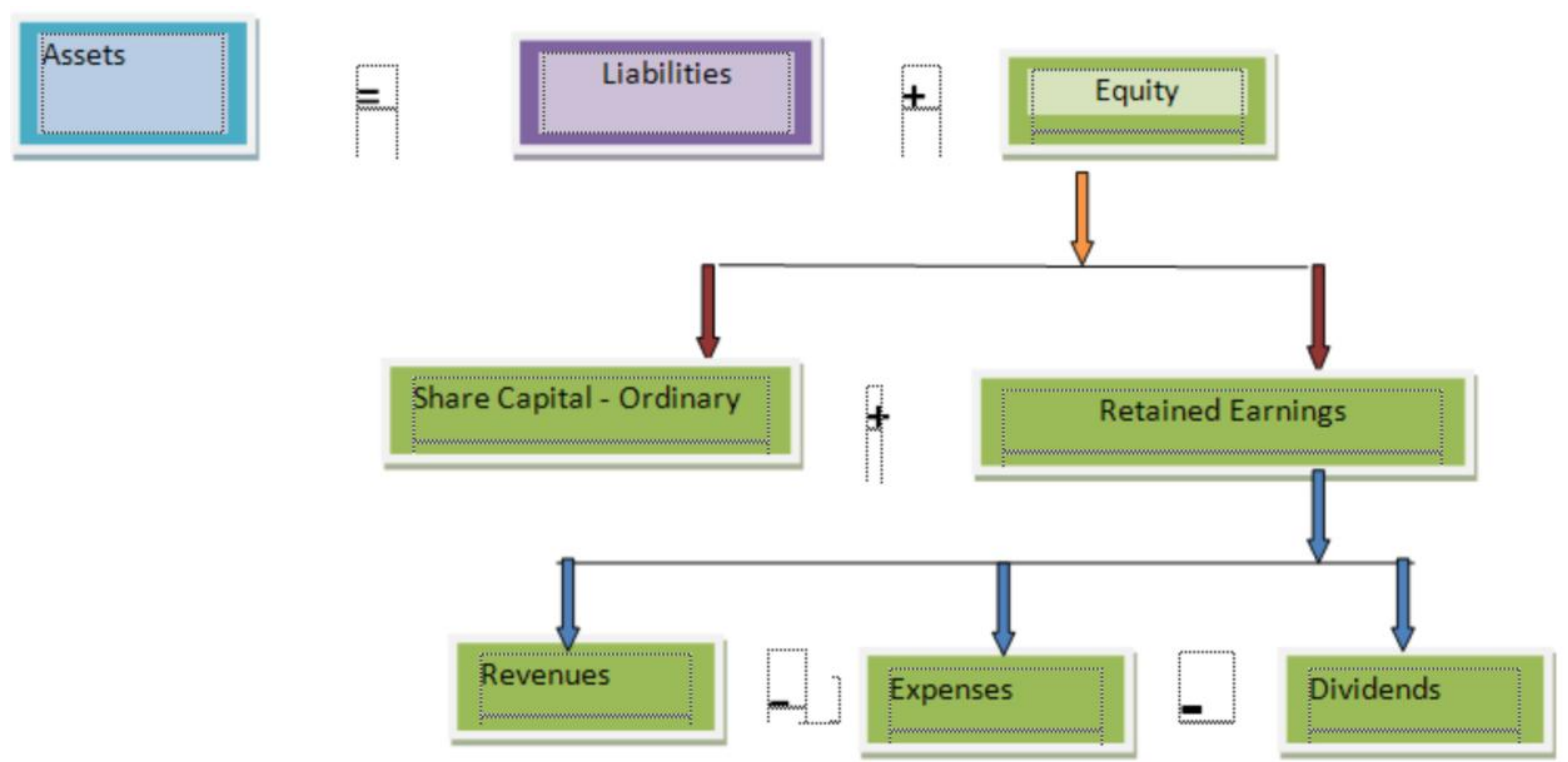

Weigant (2011) expand the basic accounting equation with better illustrate the impact of transactions on equity. Recall that equity is comprised of two parts; share capitalordinary and retained earnings. Share capital - ordinary is affected when the company issues new ordinary shares in exchange for cash. Retained earnings is affected when the company earns revenue, incurs expenses, or pays dividends. These transactions are not difficult, but understing them is important in accounting equation. The ability to analyze transactions in terms of the basic accounting equation is essential in accounting.

Lebih mendalam lagi adalah ilustrasi yang disampaikan oleh Suwardjono (2010) dengan menjelaskan artikulasi antarlaporan dapat dijelaskan dengan persamaan akuntansi dengan menunjukkan hubungan status awal dan status akhir sistem pencatatan. Tanda bintang menunjukkan bahwa komposisi telah berubah. 


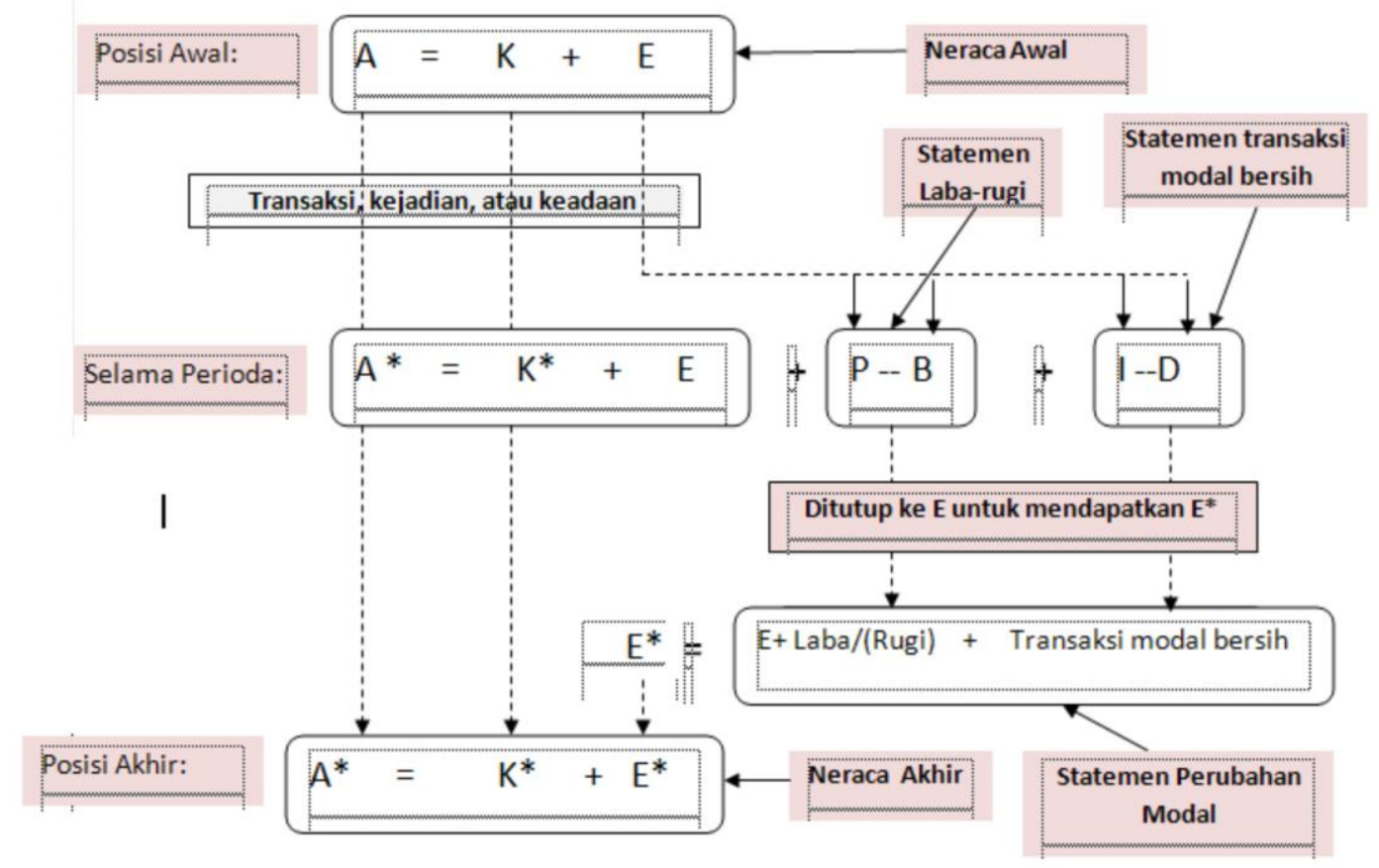

Elemen-elemen dalam laporan keuangan merupakan suatu perekayasaan dalam mengungkapkan kondisi fisik dan operasi suatu badan usaha. Pemilihan elemen-elemen ini diharapkan mampu menyediakan informasi yang dibutuhkan oleh entitas busines. Elemenelemen yang dipilih harus mampu menggambarkan realitas ekonomik perusahaan. Elemenelemen tersebut adalah aset, kewajiban, ekuitas, investasi oleh pemilik, distribusi ke pemilik, laba komprehensif, pendapatan. Biaya, untung, rugi, aliran kas dari operasi, aliran kas dari investasi, dan aliran kas dari pendanaan. Elemen-elemen tersebut akan membentuk seperangkat statemen laporan keuangan yaitu neraca, statemen laba rugi, statemen perubahan modal, statemen aliran kas, penjelasan statemen keuangan, dan informasi pelengkap.

Artikulasi adalah keterkaitan antara seperangkat statemen keuangan. Bila statemen aliran kas diperhitungkan, artikulasi terjadi untuk empat statemen keuangan. Menurut Suwardjono (2010a,b), artikulasi sebenarnya merupakan turunan atau konsekuensi dari konsep kesatuan usaha, Pendapatan (P), biaya (B), dan laba (P-B) didefinisi sebagai perubahan asset yang akhirnya mempengaruhi ekuitas. Dengan artikulasi, akan selalu dapat ditunjukkan bahwa laba dalam statemen laba rugi akan sama dengan laba dalam statemen perubahan ekuitas dan jumlah rupiah ekuitas akhir dalam statemen perubahan ekuitas akan sama dengan jumlah rupiah dalam neraca.

\section{Implikasi Bagi Dunia Pendidikan}

Kapan harus mengenalkan persamaan akuntansi agar tidak terjadi salah nalar? Pengenalan persamaan akuntansi dikenalkan kepada mahasiswa setelah mahasiswa memiliki pemahaman konseptual yang memadai tentang transakasi dan operasional perusahaan. Hal ini sesuai dengan Yusuf (1998, 2005), Thacker (1989), Sugiri dan Riyono (2008), dan Suwardjono (1999a, 1999b, 2010a, 2010b) yang menegaskan bahwa mahasiswa dikenalkan persamaan akuntansi setelah benar-benar paham bagaimana seperangkat laporan keuangan disusun atas dasar sistem pencatatan sederhana karena persamaan akuntansi merupakan abstraksi yang tidak ada maknanya kalau dihubungkan dengan unit organisasi yang menjadi subjek pelaporan. 
Lebih lanjut Suwardjono menyatakan bahwa setelah mahasiswa benar-benar paham mengenai persamaan akuntansi, barulah berlatih tentang transaksi yang lebih kompleks. Pada tahap selanjutnya pengajaran akuntansi adalah menalarkan konvensi pencatatan transaksi dalam buku besar. Implikasinya adalah dengan aturan debit dan kredit sesuai dengan persamaan akuntansi. Hal ini sesuai dengan Suwardjono (1999a, 1999b, 2010, 2011) pada tahap ini perlu kehati-hatian dan kejelian agar tidak terjadi salah sangka bahwa debit dan kredit dalam akuntansi merupakan suatu dogma. Proses akuntansi merupakan suatu proses yang bersifat sistematis dan logis. Semua proses dalam akuntansi dari mulai penjurnalan sampai dengan pelaporan dapat dilakukan oleh komputer, karena itu pembelajaran akuntansi harus lebih menekankan pada konseptual dengan implikasinya adalah mahasiswa akuntansi memiliki wawasan ilmu ekonomika dan busines yang luas.

Menurut Suwardjono (1999a, 1999b) pendekatan belajar akuntansi pengantar yang efektif adalah learning by doing and thinking, oleh karena itu perlu menekankan aspek mengapa daripada aspek bagaimana. Aspek mengapa ini berguna dalam hal menalar sebagai basis pemahaman mahasiswa. Lebih lanjut dinyatakan oleh Suwardjono bahwa sulitnya memahami akuntansi sebenarnya disebabkan oleh pendekatan yang tidak logis dalam proses pengenalan.

Kalau keterampilan teknis yang dituju, persamaan matematika tidak menimbulkan masalah, yang penting dapat menjurnal "tanpa stres." Hal ini berarti sama saja dengan menerampilkan pembelajar untuk sekadar menganalisis transaksi dan menjurnal. Padahal tujuan pembelajaran mata kuliah Akuntansi Pengantar bukan sekadar keterampilan semata. Matakuliah Akuntansi Pengantar dirancang dengan tujuan memahamkan/mengenalkan akuntansi secara utuh bukan untuk menerampilkan pembelajar untuk sekadar menganalisis transaksi dan menjurnal.

\section{DISKUSI}

Definisi seharusnya ditentukan lebih dahulu bukan definisi mengikuti persamaan. Jika menggunakan sumber penggunaan dan sumber pemerolehan dana untuk persamaan matematika nampak kalau hanya dipas-paskan dengan persamaan matematika yang dibuat oleh Warsono dkk (2009a, 2009b, 2009c). Bagaimana dengan definisi ulang mengenai sumber penggunaan dan sumber pemerolehan dana untuk persamaan matematika? Apakah tepat definisi untuk persamaan matematika tersebut? Apakah persamaan matematika tersebut mempunyai makna yang dapat diukur jumlah rupiahnya dengan reliabilitas yang tinggi? Apakah persamaan matematika tersebut mempunyai relevansi dalam keputusan pemakai informasi? Apakah informasi dalam persamaan matematika tersebut menggambarkan keadaan yang direpresentasi secara tepat, teruji, dan netral? Hal yang lebih perlu direnungkan adalah apakah perlu membuat suatu perubahan besar-besaran dalam arti mengubah rerangka konseptual dan standar agar sama dengan persamaan matematika yang dibuat oleh Warsono dkk(2009a, 2009b, 2009c)?

Suwardjono mendukung gagasan Pak Bambang Sudibyo (TA, 2005, hlm. 18), bahwa akuntansi sebagai disiplin atau bidang ilmu dapat memanfaatkan matematika tetapi akuntansi itu sendiri bukan matematika. Oleh karena itu, persamaan akuntansi yang sekarang kita kenal, walaupun dapat disebut persamaan matematis tetapi logika/penalaran matematis tidak dapat digunakan untuk menilai validitas persamaan persamaan akuntansi. Persamaan akuntansi harus dipahami dengan logika/penalaran akuntansi karena akuntansi tidak dapat bebas nilai. Persamaan akuntansi merepresentasi konsep-konsep dan definisi-definisi yang dipilih dalam pembuatan kebijakan dan bukan sebaliknya persamaan matematis menentukan konsep dan 
definisi (elemen persamaan) yang direka-reka agar persamaan matematis itu menjadi valid untuk menjelaskan gejala atau konsep akuntansi akuntansi.

\section{SIMPULAN}

Persamaan akuntansi matematika yang diuraikan dalam artikel dan buku Warsono dkk (2009a, 2009b, 2009c) menempatkan unsur-unsur dengan tanda-tanda yang sama (positif atau negatif) pada sisi yang sama. Warsono dkk (2009a, 2009b, 2009c) membuat persamaan matematika dengan memindahkan Elemen Biaya ke sisi kiri bersanding dengan elemen Aset. Namun demikian, hal tersebut tidak tepat baik definisi maupun esensinya, karena kalau harus taat terhadap standar akuntansi (keharusan untuk mengikuti PABU) maka apa yang disampaikan dalam persamaan matematika oleh Warsono dkk (2009a, 2009b, 2009c) per definisi dan esensinya sangat bertentangan dengan PABU.

PABU harus dipahami dengan benar, PABU bukan hanya kesatuan usaha seperti yang tercantum dalam Warsono dkk (2009a; 5). Seharusnya jika memahami benar mengenai konsep kesatuan usaha maka kedudukan tiap elemen persamaan akuntansi tidak dapat dipindahkan dari ruas kiri ke ruas kanan atau sebaliknya secara sembarangan. (Suwardjono, 1999a,1999b), Weigant dkk (2011), Reeve dkk (2010). Hal penting yang harus diingat adalah bahwa persamaan akuntansi harus dibedakan dengan persamaan aritmetika. Persamaan akuntansi merupakan simbol hubungan fungsional dan konseptual elemen-elemen laporan keuangan atas dasar konsep kesatuan usaha (Suwardjono, 2010:118).

Jika menggunakan persamaan akuntansi matematika seperti yang dikemukakan oleh Warsono dkk (2009a, 2009b, 2009c) maka tidak mampu menjelaskan konsep kesatuan usaha dan artikulasi antarlaporan keuangan. Persamaan akuntansi matematika tidak mencerminkan informasi apapun kecuali terjadinya penambahan aset dengan biaya. Kalau hanya merupakan sekadar jumlah biaya maka tidak ada manfaatnya karena sebenarnya Pendapatan dan Biaya merupakan satu paket yang harus dihitung lebih dahulu sehingga mengetahui jumlah laba ataupun rugi. Laba merupakan informasi yang sangat bermanfaat. Jika menggunakan persamaan matematika akan tidak menjelaskan perubahan modal yang terjadi, karena sebenarnya merupakan suatu persamaan yang satu paket jadi yang perlu dikerjakan adalah PB karena ini merupakan sumber informasi terjadinya perubahan modal.

Supaya mampu memahami persamaan akuntansi dengan benar, maka persamaan akuntansi harus dikenalkan setelah mahasiswa memahami transaksi dan operasional perusahaan secara menyeluruh. Salah strategi dalam proses pembelajaran akuntansi pengantar akan mengakibatkan salah persepsi dalam memahami persamaan akuntansi khususnya dan cara pandang terhadap akuntansi umumnya. 


\section{DAFTAR PUSTAKA}

Baridwan. 2000. Perkembangan Teori dan Penelitian Akuntansi. Jurnal Ekonomi dan Bisnis Indonesia.

Nahartyo. Ertambang. 2011. Menghindari Krisis Legitimasi: Kebijakan Pendidikan Akuntansi dari Perspektif Keperilakuan. Makalah Seminar Nasional Behavioral Economics and Business: Its Development and Its Applications to Policy-Making.

Sugiri, Slamet dan Bogat Agus Riyono, Akuntansi Pengantar 1, Edisi Ketujuh, Yogyakarta: UPP STIM YKPN, 2008.

Supriyadi. 2011. Rerangka Penelitian Aspek Keperilakuan dalam Akuntansi. Makalah Seminar Nasional Behavioral Economics and Business: Its Development and Its Applications to Policy-Making.

Suwardjono. 1992. Perkembangan Pengetahuan Akuntansi dan computer: Implikasinya Terhadap Pola Pengajaran Akuntansi. Gagasan Pengembangan Profesi dan Pendidikan Akuntansi di Indonesia. Edisi Cetakan. Yogyakarta: BPFE.

Suwardjono. 1999. Memahamkan Akuntansi di Tingkat Pengantar. Jurnal Ekonomi dan Bisnis Indonesia.

Suwardjono. 1999.Memahamkan Akuntansi dengan Penalaran dan Pendekatan Sistem. Jurnal Ekonomi dan Bisnis Indonesia.

Suwardjono. 2009. Gagasan Pengembangan Profesi dan Pendidikan Akuntansi di Indonesia. Edisi Elektronik. Yogyakarta: BPFE. www.suwardjono. com

Suwardjono. 2010. Akuntansi Pengantar 1: Proses Penciptaan Data Pendekatan Sistem. Yogyakarta: BPFE. cetakan ke empat.

Suwardjono. 2010. Teori Akuntansi: Perekayasaan Pelaporan Keuangan. Yogyakarta: BPFE. cetakan ke empat.

Thacker, Ronald. J. Accounting Principles. Prentice-Hall. Inc. Englewood Cliffs. New Jersey. 1987.

Warsono, Sony. Darmawan, Arif. Ridha, Muhammad A. 2009. Akuntansi Pengantar 1 Berbasis Matematika. Edisi 2. Asgard Chapter.

Warsono, Sony. Darmawan, Arif. Ridha, Muhammad A. 2009. Mathematics in Accounting As A Big Unaswered Question. Electronic copy available at: http://ssrn.com/abstract=1439084.

Warsono, Sony. Darmawan, Arif. Ridha, Muhammad A. 2009. Using Mathematics to Teach Accounting Principles. Electronic copy available at: http://ssrn.com/abstract=1439057 
Weygant, Jerry J. Kimmel, Paul D. Kieso, Donald E. 2011. Financial Accounting IFRS . Edition John Wiley \& Sons, Inc.

Yusuf. Al Haryono Yusuf. 2005. Dasar-dasar Akuntansi. Edisi Keenam. Yogyakarta: bagian Penerbitan STIE YKPN.

Yusuf. Al Haryono. 1998. Beberapa Catatan Tentang Pengajaran Akuntansi Pengantar. Jurnal Ekonomi dan Bisnis Indonesia. 
Sengaja Dikosongkan 